\title{
Ammatillinen kouluttaja kotouttaa kielitietoisella ohjauksella
}

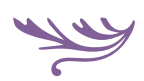

\begin{abstract}
Ammatillista koulutusta järjestetään yhä enemmän työpaikoilla, joten ammatillisen kouluttajan vastuulla on työelämän edustajien monikulttuurisuusvalmennus. Kouluttajien valmiuksia kielitietoiseen ohjaukseen on vahvistettava opettajankoulutuksessa ja työyhteisössä.
\end{abstract}

KYSYMYS AMMATILLISEN KOULUTTAJAN työtä ja osaamisvaatimuksia muuttavista tekijöistä on ajankohtainen, kun maahanmuuttajataustaisten opiskelijoiden ja tutkinnon suorittajien määrä ammatillisessa koulutuksessa kasvaa. Havaintoni perustuvat vuonna 2015 tarkastettuun väitöstutkimukseeni sekä pitkään kokemukseeni maahanmuuttajakoulutuksesta. Ammatillisen koulutuksen kontekstissa käytän 'maahanmuuttajan' sijaan termiä 'maahanmuuttajataustainen', koska ammatillisessa koulutuksessa maahanmuuttajataustainen henkilö on ensisijaisesti opiskelija ja tutkinnon suorittaja, jolla voi olla kieli- ja kulttuuritaustasta johtuvia erityistarpeita.

'Kotoutumisella' tarkoitetaan maahanmuuttajan yksilöllistä kehitystä niin, että hänellä on mahdollisuus osallistua työelämään ja yhteiskunnan toimintaan ja säilyttää samalla oma kielensä ja kulttuurinsa. 'Kotouttamisella' puolestaan tarkoitetaan viranomaisten järjestämiä kotoutumista tukevia toimia ja voimavaroja. (Saukkonen 2007, 209.)

Aikuisten maahanmuuttajien kotouttamisen keskeisiä välineitä Suomessa on koulutus, joka ensi vaiheessa on kieli- ja kotoutumiskoulutusta, mutta yhä kasvavassa määrin ammatillista koulutusta. Ammatillisen koulutuksen painoarvoa kuvaa se, että Opetushallituksen vuonna 2016 julkaisemien kotoutumiskoulutuksen uusien toteutusmallien myötä kotoutumiskoulutukseen tulee lisätä ammatillisia opintoja. Lisäksi korostetaan joustavaa siirtymistä kotoutumiskoulutuksesta ammatilliseen koulutukseen tutkinnon 
suorittajaksi. Halusta tukea maahanmuuttajataustaisten henkilöiden opiskelua ammatillisessa koulutuksessa kertoo se, että opetus- ja kulttuuriministeriö (OKM) kohdensi vuonna 2017 ammatillisen koulutuksen perusrahoituksen lisäksi 20 miljoonaa euroa erillistä rahoitusta maahanmuuttajien ammatilliseen koulutukseen.

Kotoutumiskoulutus ja ammatillinen koulutus nivoutuvat yhä tiiviimmin yhteen, ja maahanmuuttajataustaisten tutkinnon suorittajien määrä kasvaa. Ilmiö ei koske vain maahanmuuttajataustaisten opiskelijoiden sopeutumista suomalaiseen oppimisja työkulttuuriin vaan se on valtaväestöä edustavien kouluttajien, opiskelijoiden ja koko oppilaitosorganisaation oppimisprosessi.

Koska ammatillinen koulutus yleensä sisältää työssäoppimista, ja tutkintotilaisuudet ovat pääsääntöisesti työpaikoilla, monikulttuurinen oppimisympäristö laajenee työpaikoille. Siten monikulttuurisen ohjauksen haasteet koskettavat työelämänkin edustajia.

Metsäsen (2009, 116-117) mukaan monikulttuurisuus on ideologinen, yhteiskuntaan liittyvä käsite. Yksilöön liitettynä se viittaa kokemuksiin vieraista kulttuureista sekä osaamiseen, jota voidaan tarkastella esimerkiksi tietoina, taitoina ja asenteina. Monikulttuurisuus liitetään Metsäsen mukaan tyypillisesti maahanmuuttajuuteen, suvaitsevaisuuteen ja monimuotoisuuden edistämiseen yhteiskunnassa.

Ammatillinen kouluttaja on avainhenkilö, jonka odotetaan luovan edellytykset monikulttuuriselle yhteistyölle ja saattavan päättäjien ja lainsäätäjien asettamat tavoitteet käytäntöön oppilaitosten ja työssäoppimispaikkojen arjessa.

\section{AMMATILLINEN KOULUTTAJA KIELITAIDON KEHITTYMISEN OHJAAJANA}

Ammatillisessa koulutuksessa edellytetään Eurooppalaisen kielitaidon viitekehyksen B1.1-taitotasoa, joka tarkoittaa toimivaa peruskielitaitoa. Opetus- ja kulttuuriministeriön $(2017,12)$ mukaan sen alapuolelle jää perusopetuksen päättävistä maahanmuuttajataustaisista oppilaista 13 prosenttia, ja kotoutumiskoulutuksen opiskelijoista 75 prosenttia.
Kun maahanmuuttajataustainen henkilö hakeutuu ammatilliseen koulutukseen, kouluttajan on kyettävä arvioimaan hänen suomen kielen taitoaan, jota peilataan kyseisen ammatin vaatimuksiin. Samalla otetaan huomioon kielen eri osa-alueet ja niiden painopisteet ammatillisissa viestintä- ja kielenkäyttötilanteissa.

Tässä viitekehyksessä suomen kieltä tulee tarkastella sekä ammatin osana että oppimisen ja tutkinnon suorittamisen välineenä. Kuten Teräs ja Lasonen $(2013,125)$ toteavat, ammatillisen koulutuksen kontekstissa ja maahanmuuttajataustaisia opiskelijoita opetettaessa ammatin kulttuuriset käytännöt ja suomen kielen oppiminen tulee integroida ammatin oppimiseen.

Monissa tapauksissa ammatilliset opinnot vaativat varsinkin luetun ymmärtämisessä ja tekstin tuottamisessa korkeatasoisempaa suomen kielen taitoa kuin työskentely kyseisessä ammatissa. Ammatilliset opinnot painottuvat edelleen varsin paljon lukemiseen ja kirjalliseen tuottamiseen, vaikka opiskeltava ammatti painottuisi käytännön tekemiseen. Lisäksi tutkinnon suorittaminen vaatii erilaisten lomakkeiden täyttämistä, ja useiden tutkintojen perusteissa edellytetään ammattialaan liittyvien kirjallisten tuotosten, kuten kokousasiakirjojen, työsuunnitelman ja liiketoimintasuunnitelman, laatimista. Esimerkiksi sosiaali- ja terveysalan sekä kasvatusalan tutkinnot ovat kielellisesti haasteellisia, mutta haasteita sisältyy myös teknisten alojen opintoihin.

Lainsäädäntö ja viralliset, muun muassa työ- ja liikenneturvallisuutta koskevat ohjeistukset ja määräykset sekä erilaiset lupakorttikoulutukset ja -kokeet ja tekniikkaan liittyvät teoreettiset sisällöt vaativat opiskelijalta varsin hyvää suomen kielen taitoa. Liiketalouden ja hallinnon alojen tutkinnoissa haasteellisia ovat muun muassa kirjanpitoa ja isännöintiä koskeva lainsäädäntö ja erilaiset sopimusasiakirjat.

Ammatin oppimisessa kouluttajan, opiskelijan ja työelämän edustajien välinen vuorovaikutus on keskeistä. Keisala $(2012,31)$ toteaa, että viestintä ei ole vain viestien vaihtamista ja tulkintaa vaan myös identiteettien rakentamista. Ammatillisen koulutuksen tavoitteena on rakentaa suomalaisessa työelämässä tarvittavaa, täysivaltaisen työyhteisön 
jäsenyyden mahdollistavaa ammatillista identiteettiä. Se edellyttää sosiaalistumista ammattialan kielellisiin ja viestinnällisiin käytänteisiin. Tiittulan $(2005,124)$ mukaan kulttuurienväliset viestintätilanteet ovat herkkiä väärinymmärryksille. Ongelmat johtuvat usein siitä, että osallistujilla on erilaiset viestintämallit ja tietorakenteet, joiden perusteella viestintää tulkitaan.

Tutkimushavaintoni osoittavat, että kouluttajan on maahanmuuttajataustaisia opiskelijoita ohjatessaan oltava viestintätaidoiltaan joustava ja tilannereagoiva. Alkuvaiheen selkokielen jälkeen on siirryttävä yleiskieleen, sitten ammattikieleen ja lopulta ammatin erikoiskieleen. Opetettava asia on pystyttävä esittämään vaihtoehtoisilla tavoilla. Englannin tai muiden apukielten osaamisesta on hyötyä. Oman ammattialan kielenkäyttötilanteista on tunnistettava haasteelliset ja väärinymmärryksiä aiheuttavat termit ja sanonnat. Kouluttajan tulee pystyä muuntamaan omaa viestintäänsä, esimerkiksi puhetempoa ja murretta. Varsinkin ymmärtämisen varmistamisessa tarvitaan kysymistä, kertaamista, testaamista ja tarkkaa havainnointia.

\section{AMMATILLINEN KIELITAITO VAATII UUDENLAISTA YHTEISTYÖTÄ}

Ammatillisen kouluttajan ja suomi toisena kielenä (S2) -kouluttajan yhteistyö on keskeistä ammatillisen kielitaidon opettamisessa ja ohjaamisessa. S2-kouluttajalta yhteistyö vaatii rohkeaa astumista luokkahuoneesta työhalliin, rakennustyömaalle, opetuskeittiöön ja työpaikoille tutkimaan ja havainnoimaan kunkin ammattialan aitoja kielenkäyttöja viestintätilanteita. Ammatilliselta kouluttajalta prosessi edellyttää halua ottaa suomen kieli yhdeksi ammatillisen kasvun ja arvioinnin osa-alueeksi, valmiutta perehtyä kielen oppimiseen ilmiönä ja kiinnostusta etsiä keinoja niveltää suomen kielen oppiminen ammatillisten opintojen osaksi.

Teräs ja Lasonen $(2013,124)$ ovat omassa tutkimuksessaan havainneet suomen kielen ja ammatin oppimisen välisen jännitteen ammatillisessa koulutuksessa. Ammatilliset kouluttajat tiedostavat heidän mukaansa suomen kielen kaksijakoisen roolin ammatin oppimisessa ja pyrkivät integroimaan suomen kielen ja ammatin opetuksen.

Tutkimusaineistoni osoittaa monien ammatillisten kouluttajien pohtineen, voiko ammattisuomen opetuksen erottaa sisällöstä ja onko kielen opetus vaikuttavaa, jos kielen opettaja ei tunne opiskeltavan ammatin substanssia ja toimialan viestintäkulttuuria. Samalla kouluttajat toteavat, että ammatillisen kielitaidon kehittäminen tulisi aloittaa jo kotoutumiskoulutuksen aikana. Sunin mukaan suomen kielen opetukseen kaivattaisiin nykyistä enemmän integrointia ja yhteistyötä ammattiaineiden suuntaan. Kielikoulutuksen tulisi valmentaa maahanmuuttajataustaisia opiskelijoita työelämään niin, että he löytävät itselleen toimivat strategiat kielen oppimiseen. Esimerkistä käyvät tietoisen vuorovaikutustilanteiden ja osaavammilta saatavan tuen hyödyntäminen työssäoppimisen aikana. (Suni 2011,21.)

Ammatillisen kouluttajan toimintaa kielitaidon kehittymisen tukemiseksi voidaan nimittää kielitietoiseksi ohjaukseksi. Sen lähtökohtana on, että kouluttaja tiedostaa kielen merkityksen osana opettamaansa ammattialaa. Kielitietoisuus on kiinteästi sidoksissa kouluttajan tekemiin pedagogisiin valintoihin ja opetuksen organisointiin, kuten oppimisympäristöön, opetusmenetelmiin, oppimistehtäviin, ohjaukseen, arviointiin ja käytettävään oppimateriaaliin.

Yksi haastattelemani (Arola 2015, 163) ammatillinen kouluttaja kuvaa, millaisia haasteita kielen opettamiseen ammatillisessa koulutuksessa voi sisältyä. Samalla käy ilmi, kuinka ammatillisiin opintoihin siirtyminen saattaa motivoida opiskelijaa suomen kielen oppimiseen.

"Eli pitäis löytää hyvät työparit ammattiopettaja, suomen opettaja, et osa olis integroitu et sitte sehän on hirvittävän hyvä motivaatiokeino, ku istuu siä eikä ymmärrä mitään, niin sitte huomaa, että sitä kieltä on niinkö jollain tasolla opittava. Mutta silloin sen kielen oppimisen lähtökohta ei voi olla partitiivi, genetiivi. Niinkö, et se kielen oppimisen lähtökohta on jotain muuta. Mitä, en osaa sanoa. En tiiä, onko sellasta kielen opettajaa, joka olisi niin fakiiri.” 
AMMATILLINEN

KOULUTTAJA ON

KULTTUURIV ̈̈LITT ̈̈̈̈̈.

\section{AMMATILLINEN KOULUTTAJA ON TYÖELÄMÄN KULTTUURIVÄLITTÄJÄ}

Suomalaisen tutkinnon suorittaminen tukee työllistymistä, joka on keskeinen tekijä aikuisten maahanmuuttajien kotoutumisessa. Tämä havainto tulee vahvasti esiin hallituksen kotouttamista koskevassa toimintasuunnitelmassa, jonka tavoitteena on muun muassa madaltaa kotoutumiskoulutuksen ja sitä seuraavien koulutusten raja-aitoja, tehostaa aiemmin hankitun osaamisen tunnistamista sekä lisätä ammatillisen koulutuksen aikaista kielen oppimista.

Työssäoppimisen painoarvoa ammatillisessa koulutuksessa halutaan määrätietoisesti lisätä esimerkiksi ammatillisen koulutuksen reformin sisältämän koulutussopimuksen myötä.

Miten valmis työelämä sitten on ottamaan vastaan kasvavan joukon maahanmuuttajataustaisia työssäoppijoita? Millaiset valmiudet työpaikoilla on monikulttuuriseen ja kielitietoiseen ohjaukseen?

Työelämän eri toimintaympäristöissä toimiessaan ammatillinen kouluttaja on eräänlainen kulttuurivälittäjä ja asennemuokkaaja sekä työelämän edustajiin että opiskelijoihin päin. Tutkimukseni osoittaa, että työelämän edustajia rohkaistaan ottamaan maahanmuuttajataustaisia opiskelijoita työssäoppimisjaksoille, ja tutkintosuoritusten arviointiin osallistuvat työelämän edustajat perehdytetään ottamaan huomioon kielen ja kulttuurin erityispiirteet. Kouluttaja toimii opiskelijan tukena: hän ohjaa ja opettaa sekä ammattia että kyseisen alan ja työpaikan toimintakulttuuria. Lisäksi kouluttaja käyttää työelämäkontaktejaan opiskelijoiden työllistymisen tukemiseksi ja pyrkii valitsemaan työssäoppimispaikkoja, joissa ohjaus on laadukasta. Siten ammatillinen kouluttaja vastaa sekä maahanmuuttajataustaisten opiskelijan ammatillisesta kotouttamisesta, että työelämän edustajien monikulttuurisuusvalmennuksesta.
Työelämän edustajien asenteita ja ennakkoluuloja koskevat haasteet tulivat selkeästi esiin tutkimuksessani. Useat kouluttajat ovat kokeneet tehtäväkseen maahanmuuttajiin kohdistuvien ennakkoluulojen murtamisen. Tutkimusaineistossani on muutamia kuvauksia rasismista, joka on kouluttajien havaintojen mukaan ilmennyt muun muassa kiusaamisena ja turhana "juoksuttamisena". Toisaalta todetaan, että maahanmuuttajataustaista työssäoppijaa saatetaan kohdella hyvin varoen ja yliymmärtäen. Häneen ei luoteta ja häntä halutaan neuvoa ja auttaa niin paljon, ettei hän opi tekemään asioita itse. Tutkimusaineistossani (Arola 2015, 144) kouluttaja kuvaa työelämän toimintatapoja:

”Työelämässä voi olla pelkoja siitä, että häntä [maahanmuuttajaa] ei osata ohjata juuri kielitaidon puutteellisuuden vuoksi. Ei ehkä osata selittää työtapoja eikä niitä 'pinnan alla' olevia asioita. Voidaan olettaa ja tehdä tulkintoja vähän liikaa, eikä tavallaan uskalleta kysyä tai antaa reilusti ohjeita. Suomalaiset ovat toisinaan vähän liian kohteliaita antamaan palautetta. Näin ollen opiskelija ei ehkä kuule oikeita asioita vaan ikään kuin odotetaan ja oletetaan, että kyllä hän itse huomaa. On tärkeätä ohjata työelämää siihen, että maahanmuuttajataustainen henkilö ei ole tottunut olemaan oma-aloitteinen, jota meillä kuitenkin paljon odotetaan. Näin ollen hänelle on sanottava suoraan, mitä hänen halutaan tekevän.”

Julkisessa diskurssissa on toistuvasti kysytty, miten maahanmuuttajien osaaminen saadaan suomalaisen työelämän voimavaraksi ja miten heidän osaamistaan voidaan tunnistaa yhä tehokkaammin. Lasosen ja Teräksen $(2013,170)$ mukaan työpaikat ja oppilaitokset ovat avainasemassa siinä, miten maahanmuuttajien erityisyys ja osaaminen tunnistetaan.

Lisäksi on tärkeää pohtia, miten suomalaisen työelämän osaamisvaatimuksiin perustuvissa ammatillisissa tutkinnoissa voisi nykyistä paremmin hyödyntää toisessa maassa hankittua osaamista ja olisiko oppilaitoksiin ja työelämään mahdollista luoda niin sanottua kolmatta kulttuuria. Siinä toimintaa eivät Keisalan $(2012,30)$ mukaan määritä ennalta olemassa olevat oletukset, odotukset, normit tai arvot, vaan niiden luominen neuvottelevassa prosessissa. 


\section{MONIKULTTUURISUUS ON}

OPPILAITOKSEN YHTEINEN

OPPIMISPROSESSI.

Lasonen ja Teräs $(2013,170)$ toteavat ongelmalliseksi, jos maahanmuuttajataustaisten opiskelijoiden suorituksia verrataan valtaväestöä edustavien opiskelijoiden suorituksiin ja heidän odotetaan olevan samalla tasolla kuin "suomalaiset". Näin toimittaessa suomalaisuus näyttäytyy Lasosen ja Teräksen mukaan ongelmattomana ja universaalina, ja siitä tulee välittävä tekijä osaamisvaatimuksille ja osaamisen tunnustamiselle. Lisäksi he toteavat, että maahanmuuttajat saatetaan niputtaa yhdeksi ryhmäksi, johon kuuluvien yksilöiden erityisyyttä ei haluta tunnustaa.

\section{KUKAAN EI SAA JÄÄDÄ POHDINTOINEEN YKSIN}

Taitoa ja valmiutta toimia monikulttuurisessa oppimisympäristössä ei tule tarkastella vain yksittäisen kouluttajan vaan koko oppilaitosorganisaation yhteisenä oppimisprosessina, johon osallistuvat oppilaitoksen eri henkilöstöryhmät ja ihanteellisimmassa tapauksessa työelämän edustajat. Oppilaitoksen ylin johto on avainasemassa, kun luodaan yhteistä näkemystä siitä, miten maahanmuuttajataustaisiin opiskelijoihin ja monikulttuurisuuteen suhtaudutaan. Erityisen tärkeää on, että esimiehet määrätietoisesti ja selkeästi ohjaavat S2-kouluttajia ja ammatillisia kouluttajia tekemään yhteistyötä ja jakamaan osaamistaan.

Tutkimusaineistossani tulee voimakkaasti esiin kouluttajien välisen vertaistuen merkitys monikulttuurisen osaamisen kehittämisen ja työssä jaksamisen tukena. On tärkeää, että kouluttajien monikulttuurisuuspohdinnoille on foorumi, koska kuten Richardson $(2005,71)$ toteaa, keskustelemalla avoimesti kulttuurieroista voidaan välttää väärinkäsityksiä ja saavuttaa onnistunut yhteistyö.

Rose ja Potts $(2011,16)$ toteavat, että yksilö voi kehittyä kulttuurisesti responsiiviseksi vain, jos hän tiedostaa ja hyväksyy kulttuurienväliset erot. Korostamalla vain samanlaisuutta ja suhtautumalla eroihin ikään kuin värisokeasti yksilö voi heidän mukaansa vetäytyä kohtaamasta ja käsittelemästä kulttuurienvälisiä eroja. Haastattelemani (Arola 2015,187 ) ammatillinen kouluttaja kuvaa monikulttuurisen osaamisen kehittymisen haasteita:

”Joko ei niinkö pääse siihen sisälle, ei uskalla, ei halua. Se tökkii jollain tasolla, vaikka sul ois niinku hyvä aikomus, niin silloin se ei niinkö lähe rullaamaan. Tai sitte toinen on se, että ollaan sitte liian ymmärtäväisiä, liian auttavaisia ja otetaan niinkö liikaa sen maahanmuuttajan asiat omaksi ja seotaan vaikka sinne yksityiselämän puolelle tai ymmärretään liikaa, mikä ei sitten taas auta siinä oppimisessa eikä sitä maahanmuuttajaa eteenpäin. Se auttaa ainoostaan sitä ammattiopettajaa väsymään itte."

Ammatillisen koulutuksen kontekstissa kouluttajan monikulttuurinen osaaminen tarkoittaa kykyä valmentaa opiskelijoita suomalaiseen työkulttuuriin sekä ammattialakohtaisiin käytänteisiin ja tukea monikulttuurisen opiskelijaryhmän hyvää yhteistyötä ja hyvinvointia. Lisäksi kouluttaja tarvitsee monikulttuurista osaamista valmentaessaan työelämän edustajia maahanmuuttajataustaisen opiskelijan työssäoppimisen ohjaukseen sekä tutkintosuoritusten arviointiin. Monikulttuurisen osaamisen lisääminen on sekä organisaation että yksittäisen kouluttajan näkökulmasta syvällinen transformaatioprosessi, josta ei selvitä järjestämällä päivän tai kahden mittaisia monikulttuurisuusseminaareja.

Yksilöillä on hyvin erilaiset lähtökohdat ja valmiudet kehittää monikulttuurista osaamistaan. Siksi henkilöiden välillä voi olla suuriakin eroja oppimisprosessin etenemisessä ja kestossa. Monikulttuurisen osaamisen kehittyminen on pitkä ja syvällinen kasvuprosessi, jossa tarvitaan oikeaa asennetta, teoreettista perustietoa sekä omien asenteiden, ennakkoluulojen ja kokemusten reflektointia. Lisäksi oppilaitoksissa tarvitaan rakenteita, jotka mahdollistavat kouluttajien välisen vertaistuen ja synnyttävät S2-kouluttajien ja ammatillisten kouluttajien välille tiivistä ja jatkuvaa yhteistyötä. 


\section{OPPILAITOKSISSA}

\section{TARVITAAN RAKENTEITA}

VERTAISTUELLE.

\section{AMMATILLINEN OPETTAJANKOULUTUS MUUTOKSEN TUKENA}

Kun ammatilliseen koulutukseen kohdistetaan vaade tehostaa ja nopeuttaa maahanmuuttajien kotoutumista ja siirtymistä työelämään, ammatillinen kouluttaja on paljon vartijana. Tutkimusaineistostani syntyy kuva ammatillisista kouluttajista muuntautumiskykyisinä, kehittämishakuisina, monialaisina ja luovina ammattikasvattajina sekä opiskelijoiden ja työelämän monikulttuurisuusvalmentajina. Jotkut kouluttajat kuitenkin kokevat maahanmuuttajataustaisten opiskelijoiden määrän lisääntymisen kielteiseksi eivätkä halua kehittää monikulttuurisia taitojaan. Heidän tilanteensa on haasteellinen, koska kuten Pelkonen $(2005,84)$ toteaa, kulttuurienvälistä sensitiivisyyttä ei voi opettaa sille, joka ei halua kokea, oppia ja olla aktiivisen oppijan roolissa.

Tutkimukseni toi ilmi ne moninaiset muutospaineet, joita ammatilliset kouluttajat kokevat. Monikulttuurisuus on vain yksi haaste. Samaan aikaan pitäisi olla oman substanssialansa edelläkävijä ja kehittäjä ja vastata organisaation sisäisiin paineisiin, kuten tiukkeneviin resursseihin ja tehokkuusvaatimuksiin. Haastattelemani (Arola 2015, 189-190) ammatillinen kouluttaja kuvaa osuvasti kouluttajiin kohdistuvien haasteiden moninaisuutta:

"Nykymaailma on sitä, et tulee uus verkkosysteemi ja tulee uus tallennussysteemi ja tulee uudet tutkinnon perusteet ja tulee kaks uutta mamua sun ryhmään ja tulee sitä ja tätä ja sitte työaikaa vähennetään 15 prosenttia. Niin onhan se ihan oikeesti, että jos miettii itseensäkin, niin sä mietit, mitkä näistä uusista asioista mä otan hoitaakseni? Niin en tiiä, ottasinko mäkään sitä maahanmuuttajan asiaa kantaakseni jos mulla tulis muita asioita."
Kouluttajan työtä muuttavat tekijät edellyttävät myös ammatillisen opettajankoulutuksen kehittämistä. Monikulttuurisuusteemojen ei opettajankoulutuksessa enää tulisi olla valinnaisia sisältöjä, koska monikulttuurisuus ammatillisen koulutuksen arjessa on pysyvä ja yhä kasvava ilmiö. Räsäsen $(2009,247)$ mukaan kulttuurienvälisen kasvatuksen tulisi olla filosofia tai näkökulma, joka läpäisee koko opettajankoulutuksen.

Metsäsen mukaan monikulttuurisessa oppimisympäristössä tarvittavia tietoja, taitoja ja ominaisuuksia voidaan opettaa ja kehittää systemaattisesti. Opettajankoulutuksessa pitäisi olla kansainvälisessä ja monikulttuurisessa maailmassa tarvittavia osaamissisältöjä: tietoa kulttuurieroista sekä kouluttajan roolin ja identiteetin yhteydestä kulttuuritaustaan. (Metsänen 2007,219.)

Kun suunnitellaan ja toteutetaan kouluttajien monikulttuurista osaamista tukevaa koulutusta, olisi tärkeä ottaa huomioon monikulttuurisen osaamisen kehittymiselle tunnusomainen prosessinomaisuus. Siinä koulutus, kouluttajan itsereflektio ja oman toiminnan kehittäminen sekä organisaatiossa tapahtuvat, kouluttajien monikulttuurista osaamista tukevat oppimis- ja tukiprosessit yhdistyvät pitkäkestoiseksi, suunnitelmalliseksi kokonaisuudeksi. Lisäksi on tärkeä huomioida ammatillisen koulutuksen tiivis työelämäyhteys ja sen synnyttämät erityispiirteet, kuten työssäoppijan kieli- ja kulttuuritausta ohjauksessa ja arvioinnissa.

Vain harvalla ammatilliseen koulutukseen tulevalla maahanmuuttajataustaisella opiskelijalla on riittävä suomen kielen taito, joten kielen oppimisen on jatkuttava ammatillisessa koulutuksessa, missä kielitaidon kehittymistä ohjaa pääasiassa ammatillinen kouluttaja. Siksi ammatillisen opettajankoulutuksen tulisi antaa kouluttajille valmiuksia ohjata maahanmuuttajataustaisten opiskelijoiden kielitaidon kehittymistä.

Vaikka suomen kielen perusteiden opetus on siihen erikoistuneiden S2-kouluttajien työtä, ammatilliset kouluttajat tarvitsevat valmiuksia kielitietoiseen ohjaukseen. Erityisen tärkeää tämä on, koska kouluttajan tehtävä on valmentaa myös työelämän edustajat työssäoppimisen aikana tapahtuvaan kielitietoiseen ohjaukseen. Kielitietoisen ohjauksen sisällyttäminen 
opettajankoulutukseen on luontevaa, koska se liittyy kiinteästi pedagogiseen osaamiseen, joka on opettajankoulutuksen yksi ydinteema.

Toivon, että opettajakorkeakoulut tarttuvat tähän haasteeseen ja suunnittelevat ammatillisen koulutuksen ja työelämän kontekstiin sopivia koulutuskokonaisuuksia. Niiden tavoitteena on tarjota ammatillisille kouluttajille käytännön työkaluja maahanmuuttajataustaisten opiskelijoiden ammatillisen kielitaidon kehittymisen tukemiseen.

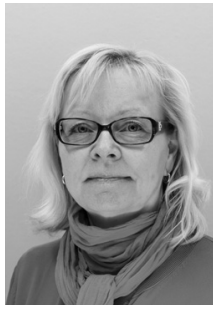

TUIJA AROLA

$\mathrm{KT}$, kehitysjohtaja

Aikuiskoulutuskeskus

Kouvola

LÄHTEET

Arola, T. (2015). Maahanmuuttajataustaisen tutkinnon suorittajan henkilökohtaistaminen näyttötutkinnoissa. Acta Universitatis Tamperensis 2032, Tampere University Press.

Keisala, K. (2012). Monikulttuurisen työyhteisön viestintä. Tampere: Tampere University Press.

Lasonen, J. \& Teräs, M. (2013). Tunnustamisen näkökulma maahanmuuttajien työllistymiseen ja ammatilliseen koulutukseen. Teoksessa Brunila, K., Hakala, K., Lahelma, E. \& Teittinen, A. (toim.) Ammatillinen koulutus ja yhteiskunnalliset eronteot. Helsinki: Gaudeamus, 154-170.

Metsänen, R. (2007). Opettajana globaaleissa ympäristöissä. Teoksessa Jääskeläinen, M., Laukia, J., Luukkainen, O., Mutka, U. \& Remes, P. (toim.) Ammattikasvatuksen soihdunkantoa. Kymmenen vuotta opettajankoulutusta ammatillisissa opettajakorkeakouluissa. Jyväskylä: PS-Kustannus, 207-221.

Metsänen, R. (2009). Monikulttuurinen ohjaus käytännössä - vanhaa ja uutta, omaa ja lainattua, läheltä ja kaukaa. Teoksessa Helander, J. (toim.) Ammatillisen opettajan käsikirja. Hämeenlinna: Hämeen ammattikorkeakoulu, 115-124.

Opetus- ja kulttuuriministeriö. (2017) Maahanmuuttajien koulutuspolut ja integrointi. Kipupisteet ja toimenpide-esitykset II. Opetus- ja kulttuuriministeriön julkaisuja 2017:5.

Pelkonen, P. (2005). Intercultural Learning for International Cooperation. Teoksessa Räsänen, R. \& San. J. (Eds.) Conditions for Intercultural Learning and Co-operation. Research in Educational Sciences 23. Finnish Educational Research Association, 69-87.
Richardson, P. (2005). Kulttuurisesti monimuotoisen työyhteisön johtaminen. Teoksessa Pitkänen, P. (toim.) Kulttuurien välinen työ. Helsinki: Edita, 63-75.

Rose, D. G. \& Potts, A. D. (2011). Examining Teacher Candidate Resistance to Diversity: What Can Teacher Educators Learn? International Journal of Multicultural Education 13 (2), 1-19.

Räsänen, R. (2009). 60-vuotinen inmisoikeusprosessi ja kasvatus kulttuurienväliseen vuoropuheluun. Teoksessa Jaatinen, R., Kohonen, V. \& Moilanen P. (toim.) Kielikasvatus, opettajuus ja kulttuurienvälinen toimijuus. Saarijärvi: OKKA-säätiö, 237-249.

Saukkonen, P. 2007. Politiikka monikulttuurisessa yhteiskunnassa. Helsinki: WSOY.

Suni, M. (2011). Missä ja miten maahanmuuttajat kehittävät ammatillista kielitaitoaan?

Ammattikasvatuksen Aikakauskirja 13(2). Työelämän ja ammatillisen koulutuksen monikulttuuristuminen. Helsinki: OKKA-säätiö, 8-22.

Teräs, M. \& Lasonen, J. (2013). The Development of Teachers' Intercultural Competence Using a Change Laboratory Method. Vocations and Learning 6 (1), 107-134.

Tiittula, L. (2005). Monikulttuurisuus ja viestintä. Teoksessa Pitkänen, P. (toim.) Kulttuurien välinen työ. Helsinki: Edita, 123-135. 